\title{
ENGRAVING OF THE INVERTED INSCRIPTIONS ON CORAL BUTTON RINGS WITH AN ORGANIC ACID
}

\author{
Muhammed Abd al-Sattar OTHMAN \\ Faculty of Archaeology - Sohag University \\ m.abdal-sattar.uthman@art.sohag.edu.eg
}

\begin{abstract}
This paper deals with an important text written by Al-Tīfashāi (580-651 AH/1184-1253 AD) in his famous book "A'zhar al-a' fkar fì gawahīir ala'hgar" (=The flowers of thoughts about precious stones). Al-Tīfashāi describes a distinguished method of engraving inscription on coral stone rings by "khall Qamr haziq" which means the Glacial acetic acid $(\mathrm{CH} 3 \mathrm{COOH})$. This organic acid is suitable for engraving inscriptions on the surface of coral stone rings.

The author interprets Al-Tīfashāi's text following his practical steps, tools, materials used, and the suitable duration for engraving inscription on coral stone rings using this organic acid.

From the archaeological point of view, dating the first application of this method on coral button rings "seals" is crucial. The author endeavours to date the coral button rings preserved in the Islamic Art Museum of Cairo, and to prove that this organic acid was the engraving method for the inscriptions.

The author proved that engraving inscriptions with organic acid had been applied before using sulphuric acid $\mathrm{H} 2 \mathrm{SO} 4$.

Finding out this method of engraving inscriptions by an organic acid. Dating its application during the early Islamic period presents a new scientific contribution to methods of engraving inscriptions (normal or inverted) on archaeological Islamic objects.
\end{abstract}

\section{KEYWORDS}

Al-Tīfashāi; Islamic Inscriptions; Glacial acetic acid;

Stone ring, Coral, Coating.
الملخص

تناول هذا البحث دراسة لطريقة غير معروفة في

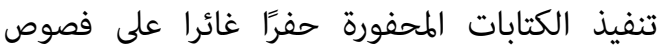

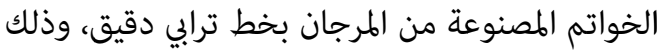

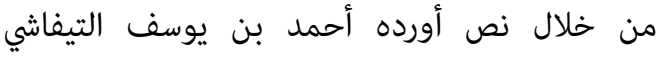
(ت:651هـ/1253م) في كتابه "أزهار الأفكار في جواهر آوردي الأحجار" ذكر فيه أنه قام بنفسه بتابه "آنار الأبيقها على

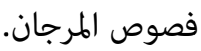
وقد تناول البحث بالدراسة التفصيلية هذه الطريقة

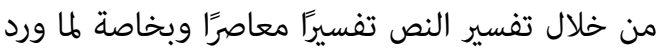
به من مصطلحات، كما قام الباحث باثبات البات تنفيذ هذه الطريقة على فصي خاتمين من المرجان محفوظين

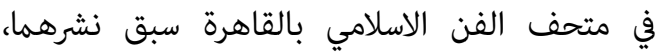

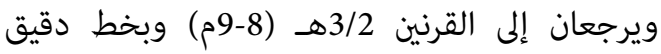
يناسب المساحة المتاحة لا يمكن تنفيذه بالطرين الطريقة العادية التي أشارت الدراسات السابقة إليها وهي

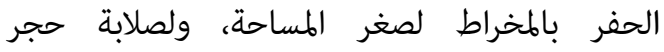

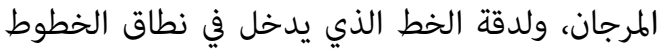

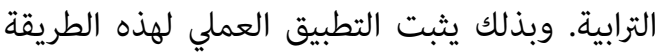

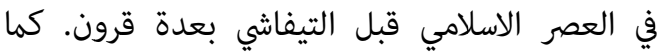

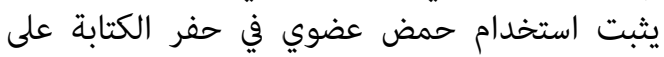
المواد الصلبة وهو تطبيق يسبق استخدام الأحماض غيرالعضوية والتي تطورت إلى الطباعة بالزنكوغراف. وبذلك يتضح أن هذه الطريقة تمثل مرحلة مهمة من الطن مراحل تاريخ الطباعة.

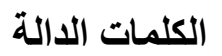

التيفاشي، النقوش الإسلامية، حامض الخليك، فص اله

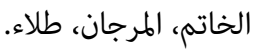




\section{INTRODUCTION}

In Islamic period, coral has been used to make stone rings, necklaces and rosaries. Many countries produce coral, among which Tunisia (in Arabic sources E'frī $q \overline{1} y \bar{a})$ which had been exporting coral to Alexandria in the Middle Ages $\left(6^{\text {th }} \mathrm{H} / 12^{\text {th }} \mathrm{AD}\right)$. Alexandria was known as an industrial centre manufacturing coral product. ${ }^{1}$ Coral is distinct for its beautiful colours, white and red, a pattern cited in the holy Quran. ${ }^{2}$ Coral stone rings are regularly inscribed. Craftsmen used small letters to engrave inscriptions fitting the small size of the surface of the coral stone rings. It is often believed that chisels were used for engraving such inscriptions on coral, though evidence points to the contrary. Organic acid (glacial acetic acid) appears to have been an available resource for these craftsmen to develop this craft. Considering AlTîfashāi reference, the dating of the apparition of such technique is explored. Adopting an inductive approach to read Al-Tīfashāi, historic and archaeological evidence are also examined to identify the first occurrences of this method.

The word "Morgan" in Greek language is Marginto, in Latin language is Margarita, ${ }^{3}$ and in English is Coral. The hardness of coral is 3.25, specific gravity is 2.65 and chemical composition is $\left(\mathrm{CaCO}_{3}\right){ }^{4}$

\section{THE MEANING OF AL-TĪFASHĀI'S TEXT}

This section provides an interpretation of applying the process of using glacial acetic acid in engraving inscriptions on coral stone rings. Before discovering Al-Tīfashāi text the archaeologists thought that all engraved inscriptions on solid material had been engraved by the chisel. It is however difficult and perhaps impossible to use a chisel to engrave the inscription on the surface of coral stone rings, because of its hardness (3.25), its small size (between 15 and $20 \mathrm{~mm}$ ) and its thickness (3 mm).

Al-Tîfashāi gave a detailed account of the method used to engrave inscriptions on coral stone rings. In the following Arabic text, he points out:

$$
\begin{aligned}
& \text { "خواصه [يقصد المرجان] في معدنه أنه إذا أُلقي في الذل لان وإن تُرك فيه إنحل وذاب، إن من الناس من بتخذ }
\end{aligned}
$$

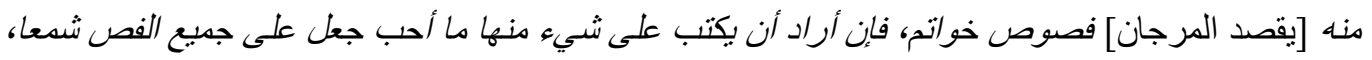

\footnotetext{
${ }^{1}$ Al-Tīfashāi, A zhar al-a'fkar, p.185

${ }^{2}$ Al Qūran: Sürat al Rahman, No.55 verse No. 22

${ }^{3}$ For further data about coral see: Al-Tīfashāi (Ahmād bīn Yoūsīf), A zhar al-a 'fkar fí gawah̄îr ala'hgar, Verification; Mūhamīd Yoūsīf \& Mahmoūd Basyūon̄̄ Khafagī. Publish by. Al-Hayā alMīsrayyah al-A'amah Līlkūtūb, 1977.pp.178-188; Mūhamīd Mūhamīd Kūzlūk, al-a'hgar al-Karīma wa al-Ma 'adīn al-Nafissa, Maktabaīt Bīn Sīna, 2003, Pp.146-152; Al-Singarī (Mūhamīd bin ībrahim alAnsarī 749 A.H/1348A.D), Nakhbat al-Dhakhaer fí Ahwal al Gwahīr, maktab Dhakhaer al-Motanab Maktabīy, Cairo, p. 89.

${ }^{4}$ Al-Tīfashāi, A'zhar al-a fkar, p.313.
} 


$$
\begin{aligned}
& \text { ثم عدد إلى موضع النقش منه فكتب فيه برأس إبرة ما أحب حتى بيكثف الثهع عن موضع الكتابة لا غبر، ثم }
\end{aligned}
$$

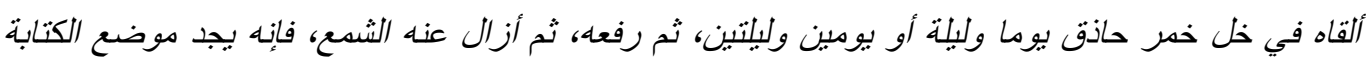

$$
\begin{aligned}
& \text { محفورا، قد تآكل بالخل، وبقية الفص والخاتم على حاله لم بتغبر، وقد جربنا ذلك وفعلناه مرارا، فكان ما } \\
& \text { زكرنا. }
\end{aligned}
$$

"khūash [yaqsad al-mūrgan] fì maa'danīh anah e'dha aūlgaīa fì al-khal līan waa'n türak fìhī e'nhal wdhab, e'n mìn al-nas man yatakhïdh mīnhū [yaqsad al-mürgan] fìsūs khawatìm, fa'na 'rad a'n yaktūab a'la shīa' mīnha ma a'hab gaa 'l a'lagamīa' al-fas shamaa', thūma a 'mad i'la mūta' al-naqīsh mīnhū fakatab fìh bīra's i'bra ma a'hab hatā yankashīf al-shamaa' a'n mütaa' al-kītaba la ghaīr, thūma alqah fì khal khamar hadhīq yaūm wa lā̄la awū yaūmaīn wa laīlatīn, thūma rafaa 'hw, thūma azal a'nhw al-shamaa', fa'nahw yagaīd mūta' al-kītaba mahfura, qad ta'kūl bilkhal, wa baqīàt al-fas wa al-khatīm a la haliah lam yatakhīr, wa qad garabna dhalīk wa faa 'nah mìrara fakan ma dhakrnah."

This text of Al-Tĩfashāi shows that some people make their button rings from coral. It also explains the procedure if someone desires to write an inscription on his coral button ring:

1. He must coat the coral button ring (or the whole ring) with wax.

2. Then he writes the desired inscription using a needle with a thin head to engrave on the wax coating.

3. After finishing the engraving process, the coral button ring is placed in "khall khamr haziq." "khall" means in Arabic حامض الخليك (hamāī al-khalīk), which is acetic acid, for a period of one to two days. "khall khamr" is acetic acid which has been prepared from organic produce, wood or fruits such as apple and dates, by fermentation. The expression "khall khamr haziq" means that it is a concentrated solution of acetic acid $^{6}$ (degree of concentration 95-100\%). The scientific name of this concentrated acetic acid is glacial acetic acid. The "khall khamr haziq" is thus the glacial acetic acid which has been prepared by the fermentation method. ${ }^{7}$

4. Finally, the coral button ring is taken out of the glacial acetic acid and the wax layer which coats the coral button ring is removed. Hence, the final appearance is the coral button ring with clear engraved inscriptions.

Al-Tīfashāi also reported that common people engraved inscriptions on coral stone rings by themselves. This means that the method and the application of this technique were not restricted to specific craftsmen.

Al-Tîfashāi pointed out that the needle was the tool used to engrave inscriptions. The thin head of the needle is the only suitable tool to engrave inscriptions perfectly on the

${ }^{5}$ Al-Tïfashäi, A'zhar al-a'fkar, p.182.

${ }^{6}$ ìbn Manzūr, līsan al- $\boldsymbol{a}$ rab, dar șadeīr, Beirut. Vol.3. p.66.

${ }^{7}$ Finar I.L. Organic chemistry. Longman group Limited. $6^{\text {th }}$ ed. Pp 240-241

- 233 - Engraving of the Inverted Inscriptions on Coral Button Rings with an Organic Acid 
surface of the wax. The duration for the process of immersing the coral button ring in glacial acetic acid ranges between one day and two days. The author suggests that there is a relation between this duration and the following factors:

1. The degree of concentration of the glacial acetic acid (95-100\%).

2. The depth of engraving inscriptions which affected the corrosion of the coral button ring by glacial acetic acid.

3. The composition of the coral button ring itself.

Finally, Al-Tîfashāi emphasized that he tested this technique several times and his experiments had been successful in engraving inscriptions on the surface of stone rings. This proves that Al-Tīfashāi himself was an expert in engraving inscriptions on coral stone rings. The use of wax in this process shows that it was popular knowledge in the making of coral stone rings, that all were aware of the function of wax as an insulator.

\section{When was this method of glacial acetic acid used to engrave inscriptions on coral stone?}

The mention in Al-Tīfashāi's text demonstrates that this technique of using glacial acetic acid to engrave inscriptions on coral stone rings was common in the period of Al-Tīfashāi. One must explore the Islamic sources to identify whether it has been known prior the time of Al-Tîfashāi. Fortunately, two coral button rings (or seals) with engraved and inverted inscriptions are preserved in the collection of the Islamic Art Museum in Cairo.

The first one (No. 1465) is oval, with a maximum length of $1.7 \mathrm{~cm}$, and maximum width of $1.2 \mathrm{~cm}$. The thickness of this coral button ring is $3 \mathrm{~mm} .{ }^{8}$ There is a line of angular Kufic engraved and inverted inscription on the surface of this coral button ring, which is $8 \mathrm{~mm}$ long. The letters are similar in shape to that of the angular Kufic inscriptions of the second half of the $2^{\text {nd }}$ century A.H $\left(8^{\text {th }} \mathrm{CE}\right) .{ }^{9}$ The shape of letters aldal-dal (د) (s) are also familiar in the $2^{\text {nd }}$ century A.H $\left(8^{\text {th }} \mathrm{CE}\right)$. According to these, the author dates this coral button ring from the second half of the $2^{\text {nd }}$ century A.H. to the first half of the $3^{\text {rd }}$ century A.H. $\left(9^{\text {th }}\right.$ century CE) (Pl. 1, Fig. 1).

\footnotetext{
${ }^{8}$ Fahmī, șanag al-sīka fì Fagīr al-īslam, Dar al-kūtab.1957, pp.142-238; Balog.B, Ummyad, Abbasid and Tulunid Glass weights, New York. 1976. P.No.277-649.plate XVI-XXXX

${ }^{9}$ Fahmī, Islamic Seals and Maulds from the first century of Hegra to the end of Ottoman period, The through studying the collection Museum of Islamic Art in Cairo artistically and archaeologically. Ph.D. Manuscript. Cairo University. Faculty of Archaeology.2000.p.164. (plate. 57, 3A and fig.3B) \& Mohammed Fahmy: Seals and Maulds. p. 164.
}

Engraving of the Inverted Inscriptions on Coral Button Rings with an Organic Acid - 234 - 

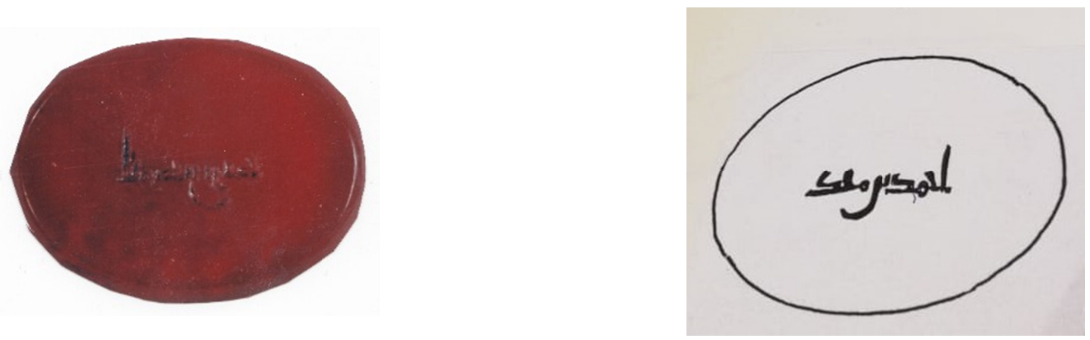

P1. 1 \& Fig1 Fahmī, M. 2000.

The second coral button ring (No. 18593) is also made of an oval-shaped red coral. Its maximum length is $1.9 \mathrm{~cm}$, maximum width $1.2 \mathrm{~cm}$, and its weight $2.92 \mathrm{gm}(\mathrm{Pl} .2$, Fig. 2). ${ }^{10}$ The surface of this coral button ring was engraved with an inverted inscription in two lines of angular Kufic. It reads (Pl. 2, Fig. 2) of these laid on two lines:

1. داوود بن إياد (Dawūd bīn ìyad)

2. ابن النعمان (îbn al-noa'man)
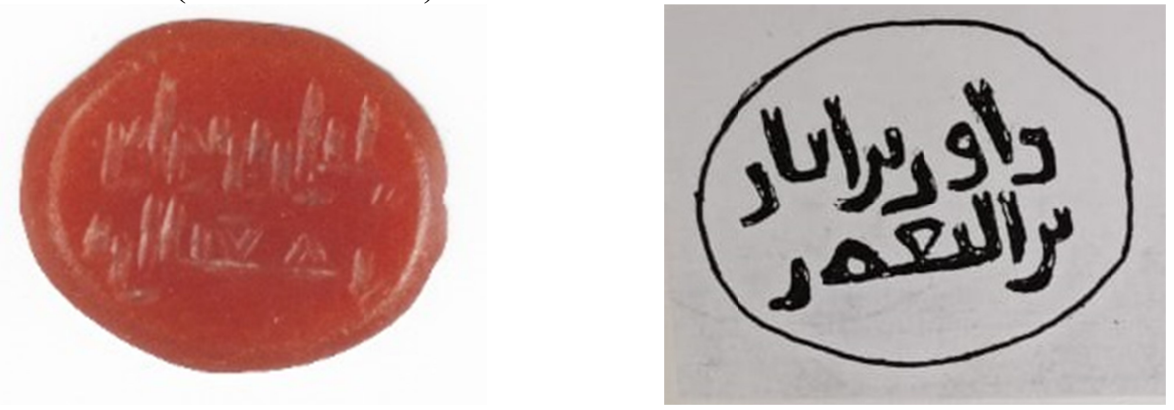

Pl.2 and Fig.2 Fahmī, M. 2000

أ، ل، ب ، Lam, $\left.B a a^{\prime}, Y a a^{\prime}\right)$. The upper parts of these letters were drawn with a forked end", like a snake tongue. This feature is regularly seen in drawing angular Kufic inscriptions at the end of the $2^{\text {nd }}$ century A.H. $\left(8^{\text {th }} \mathrm{CE}\right)$ and the first half of $3^{\text {rd }}$ century A.H. $\left(9^{\text {th }}\right.$ century $\mathrm{CE}$ ).

These two red coral button rings with engraved and inverted inscriptions support the author's hypothesis about the technique of organic glacial acetic acid being used to engrave inscriptions in the $2^{\text {nd }}-3^{\text {rd }}$ A.H. centuries/ $8^{\text {th }}-9^{\text {th }}$ centuries CE). The author agrees with Al-Tîfashāi's view concerning the effects of immersing coral in glacial acetic acid as the engraved parts of the two button rings show a white colour regardless of the original red colour of the coral. The main reason for this change of colour is due to the usage of glacial acetic acid in engraving inscriptions. This aspect also has been assured by the correct note of Al-Tīfashāi about characters of coral. One can safely argue that these two coral button rings were treated with glacial acetic acid in the Islamic period. This demonstrates that the Arabs knew this method in the $2^{\text {nd }}-3^{\text {rd }}$ centuries A.H. $\left(8^{\text {th }}-9^{\text {th }}\right.$ centuries CE).

${ }^{10}$ Fahmī. Islamic Seal. P.164

- 235 - Engraving of the Inverted Inscriptions on Coral Button Rings with an Organic Acid 
It is a well-known fact that the European chemist Andreas Libavius in the $16^{\text {th }}$ century $\mathrm{CE}$ had prepared the inorganic sulfuric acid $\left(\mathrm{H}_{2} \mathrm{SO}_{4}\right) .{ }^{11}$ It then became the main component in the zincography method of printing photographs. The effect of corrosion of zinc by sulfuric acid is similar to the effect of corrosion in coral by the glacial acetic acid. The two acids were manipulated to engrave on solid materials.

The beginning of this idea and method, "engraving inscriptions by acids", began with organic acid, namely the glacial acetic acid. After seven centuries Libavius discovered sulfuric acid which was then used in the zincography.

\section{CONCLUSIONS}

The main purpose of this paper was to identify the chemical method used by Arabs for engraving inscriptions on coral button rings, as early as the $2^{\text {nd }}-3^{\text {rd }}$ centuries A.H. / $8^{\text {th }}-9^{\text {th }}$ centuries CE. This method to engrave inscriptions on solids with acid is pioneering, and was rediscovered in the $16^{\text {th }}$ century CE to enable the history of printing.

The application of this technique is the most reliable method to engrave inscriptions on coral button rings, which are very small, solid, and very thin.

\footnotetext{
${ }^{11}$ Cathy Cobb\& Harold Golwhite, Ibdaat al Nar. Tarikh al kemyaa al Muthir min al symyaa ela asr al zarri (Creation of fire chemistry lively history from Alchemy to atomic age) translated by Fathalla Alsheikh, Kuwait, 2001.p.119
} 


\section{REFERENCES}

1. Holy Quran.

2. Al-Singarī (Mūhamīd bin ībrahim al-Ansarī 749 A.H/1348A.D), Nakhbat alDhakhaer fĩ Ahwal al Gwahìr, maktab Dḥakhaer al-Motanab Maktabīy, Cairo.

3. Al-Tīfashāi (Ahmād bīn Yoūsīf), A z'zhar al-a'fkar fì gawaḥīr al-a'hgar, Verification; Mūhamīd Yoūsīf Hasan and Mahmoūd Basyūonī Khafagī. Publish by. Al-Hayā al-Mīsrayyah al-A'amah Līlkūtūb, 1977.

4. Balog.B, Ummyad, Abbasid and Tulunid Glass weights, New York. 1976.

5. Fahmī .M, șanag al-sīka fì Fagīr al-īslam, Dar al-kūtab.1957.

6. Fahmī .M: Islamic Seals and Maulds from the first century of Hegra to the end of Ottoman period, The through studying the collection Museum of Islamic Art in Cairo artistically and archaeologically. Ph.D. Cairo (univ). Faculty of Archaeology.2000

7. ībn Manzūr (Gamaladdin Mohamed bin Makram): līsan al- a $r a b$, dar șadeīr, Beirut.

8. Mūhamīd ( Kūzlūk) \$ Mahmoūd (Khafagī), al-a'hgar al-Karīma wa alMa adīn al-Nafìsa, Maktabaīt Bīn Sīna, 2003.

9. Finar I.L. Organic chemistry. Longman group Limited. $6^{\text {th }}$ ed.

10. Cathy Cobb \& Harold Golwhite, Ibdaat al Nar. Tarikh al kemyaa al Muthir min al symyaa ela asr al zarri (Creation of fire chemistry lively history from Alchemy to atomic age) translated by Fathalla Alsheikh, Kuwait, 2001. 